\title{
Evaluation of Geodetic Reference System for Reconstruction of Latvia - Belarus State Border
}

\author{
Armands CELMS ${ }^{1}$, Ihor TREVOHO ${ }^{2}$, Aivars RATKEVIČS ${ }^{1,3}$, \\ Vivita PUĶITTE ${ }^{1}$, Ļubova S̆UĻAKOVA ${ }^{4}$ \\ ${ }^{1}$ Latvia University of Life Sciences and Technologies, Department of Land Management and \\ Geodesy, Akadēmijas iela 19, Jelgava, LV-3001, Latvia; ${ }^{2}$ Lviv Polytechnic National University \\ Institute of Geodesy, 6 Karpinskyi Str., Lviv, Ukraine; ${ }^{3}$ Latvian Geospatial Information Agency, \\ Ojāra Vācieša Str. 43, Riga, LV-1004, Latvia; ${ }^{4}$ Riga Technical University, Department of \\ Geomatics, Meža Str.1 k-1 - 116, Riga, LV-1048, Latvia

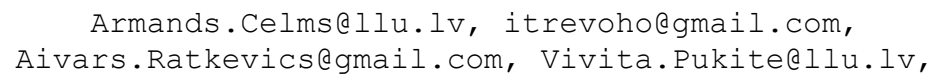

\begin{abstract}
Meaning of application of technologies of geodetical and cartographic works in the processes of state border demarcation works shall be considered as the first main technical position in the course of their practical realization and maintains its importance also in further border maintenance measures. On 21 February, 1994, the agreement was concluded in order to determine Latvian - Belarussian state border, Mixed Border Demarcation Commission was formed. In 2015, Latvia concluded with Belarus State Border Regime Agreement, where they agreed on maintenance of the joint border. As every geodetic system, also it accrues deviations from the original parameters. It is stated that the earlier established system does not comply not only with requirements of completion of works of contemporary geodesy, but also with criteria determined during the establishment. The study concerns Latvian - Belarussian state border in the framework of fulfilment of the concluded border maintenance agreement 2016-2018.
\end{abstract}

Keywords: State Border, surveying, geodetic reference system, GNSS.

\section{Introduction}

Determination of Latvian - Belarussian state border - demarcation was officially completed on 6 December 2008. So one of essential sections of obligations of the transnational agreement concluded on 21 February, 1994, on determination of joint Latvian - Belarussian state border was fulfilled. As every manmade object and natural terrain object has quality to get older and lose its original functionality in the course of time. For the keeping of functionality exploiters of the object are forced to invest resources and time, as they take object maintenance measures. The maintenance works and measures in the case of state border are necessary also due to changes of terrain situation of the border caused by seasonal climatic changes and due to adverse, often devastating effect on situation of location of the border and its fixation elements constructions (Arhipov, 2018). According to rules accepted in construction classics, 
maintainers or users of the object shall start the organization of object maintenance works immediately after the completion of construction works (Sereda, 2018). Also in the case of Latvian - Belarussian border, as this was understood, development of an according transnational agreement was organized. As a result, in 2015, Agreement of State Border Regime was concluded with Belarus, in which parts agree upon the maintenance of the joint border. As the realization of the agreement was started, the Joint Transnational Border Commission was established. Control of the actual location of the state border in terrain and control of compliance of its depiction with border demarcation documents is determined as one of main tasks of maintenance of the state border. In the framework of these works, comparison of the border and its fixation elements with demarcation documents is performed. Discrepancies are found and fixed in documents, surveyed and their parameters are determined. Proposals for the elimination of discrepancies are developed, their elimination is organized or initiatives on elimination of discrepancies are submitted to the government of the country (Arhipov, 2018). That is in cases, when parameters of changes exceed authority given to the Commission for the elimination of changes. Geodetic surveying works and their accuracy have the most essential importance in the determination of discrepancy parameters and putting them into documents (Celms, 2018). Similarly, as it was in processes of border installation demarcation. As it was stated, when Latvian experience was evaluated - in works of demarcation of its borders, in order to obtain accuracy and credibility of geodetic measurements, jointly established state border geodetic reference system had essential importance in all cases (Turner, 2008). Certainly, firstly, the possibility to use the joint geodetic reference system established at the beginning of demarcation works was considered (Burban, 1999). However, after first joint measurements specialists came to conclusion that it is necessary to restore, transform and modernize the geodetic reference system earlier according to technologic requirements of state of art.

\section{Materials and methods}

Already in the first year of activities of Joint Transnational Border Commission, organization of inspection of the state border was started. Inspection was performed in 2016 by staff of border guard of both countries. Partially materials submitted by geoinformation specialists concerning the possible changes of situation of location of state border were guiding (Celms, 2018). Places of possible changes were identified by use of remote sensing technologies and by use of aerial photograph materials produced in 2014 (Sereda, 2018). Totally, 17 places were identified; all places were connected with border rivers and brooks. According to results of inspection, it was determined that for the further monitoring in 2017 by use of already professional geodetic measurement methods 10 border sections will be used. All are located on brook Sarjanka and river Daugava. Already the first results of geodetic measurements showed that the geodetic reference network of the border established earlier (1999-2006) does not provide credible and accurate transformation of measurements between geodetic coordinate systems used in both countries (Ratkevics et al., 2016a).

In individual places, discrepancies of the direct transformation (for example, on brook Sarjanka) reached more than 100 meter great distances. Measurements of stated changed in river Daugava also demonstrated considerable shifts against demarcation map and orthophoto map produced in Latvia in 2014 (See Fig. 1 and 2). 


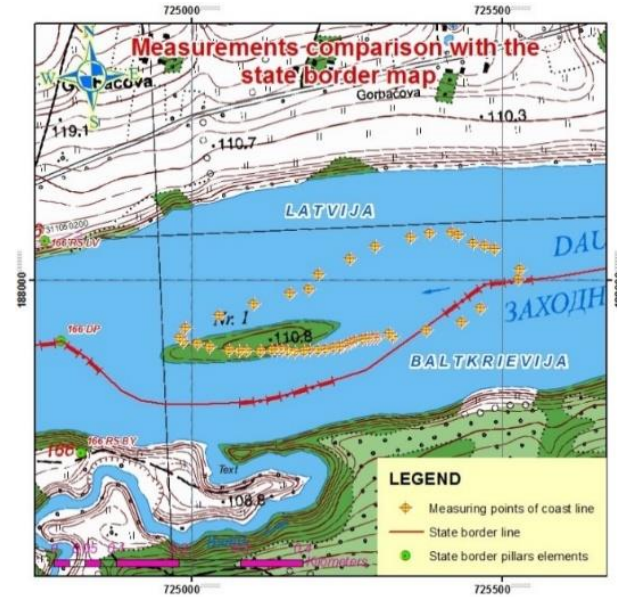

Figure 1. Measurements comparison with the demarcation map

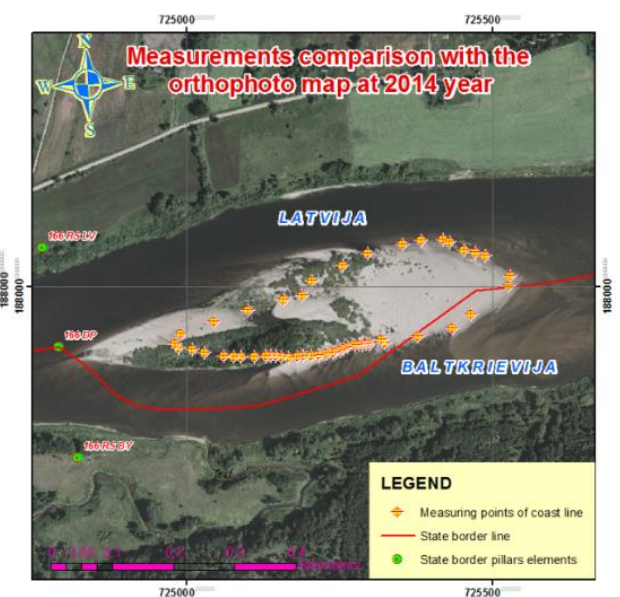

Figure 2. Measurements comparison with orthophoto map at year 2014

During demarcation, in order to get possibilities of qualitative recalculation from coordinate system WGS-84 to coordinate system of year 1942, points of state geodetic network of the class 1 and 2 located near the border: Behova (Бехова), Ozolkalni (Озолкални), Šatilova gora (Шатилова Гора), Tepljuki (Теплюки), Urbanovo (Урбаново), Lipovka (Липовка), Berezki (Березки), Mikuti (Микуты), Kirjaniški (Кирянишки), Stankoviči (Станковичи), Ušanišķi (Ушанишки) were selected (Ratkevics et al., 2016a). Performance of unified joint geodetic measurements on these points and alignment of results was not made because recently, until 1991, these points were in unified coordinate system of year 1942 (Ratkevics et al., 2016b). Already in that time such solution was not the most successful one, as further researches by Latvian specialists proved (see Table 1).

Table 1. Valuation of quality of geodetic reference network of Latvian State Borders (Ratkevics et al, 2016a).

\begin{tabular}{|l|l|l|c|l|}
\hline \multicolumn{1}{|c|}{ Country } & \multicolumn{1}{|c|}{$\begin{array}{c}\text { Network } \\
\text { quality }\end{array}$} & \multicolumn{2}{|c|}{ Geodetic works accuracy } & \multicolumn{1}{|c|}{$\begin{array}{c}\text { Demarcation } \\
\text { Maps } \\
\text { accuracy }\end{array}$} \\
\cline { 2 - 5 } & $\begin{array}{l}\text { mean square } \\
\text { error }\end{array}$ & $\begin{array}{l}\text { mean square } \\
\text { error }\end{array}$ & $\begin{array}{c}\text { max } \\
\text { deviation }\end{array}$ & $\begin{array}{c}\text { mean square } \\
\text { error }\end{array}$ \\
\hline Estonia & No & $\pm 1,40 \mathrm{~m}$ & $12.00 \mathrm{~m}$ & $\pm 6 \mathrm{~m}$. \\
\hline Lithuania & $\begin{array}{l}\text { Not } \\
\text { validation }\end{array}$ & $\pm 0,15 \mathrm{~m}$. & $0.30 \mathrm{~m}$ & $\pm 2 \mathrm{~m}$ \\
\hline Belarus & $\begin{array}{l}\text { Not } \\
\text { validation }\end{array}$ & $\pm 0,21 \mathrm{~m}$. & $0.42 \mathrm{~m}$ & $\pm 2 \mathrm{~m}$ \\
\hline $\begin{array}{l}\text { Cross } \\
\text { border } \\
\text { point } \\
\text { "Neverica" }\end{array}$ & $\pm 0.05 \mathrm{~m}$ & $\pm 0,05 \mathrm{~m}$. & $0.10 \mathrm{~m}$. & $\begin{array}{l}\text { M1:500 } \\
\text { topography } \\
\text { measuring } \\
\text { accuracy }\end{array}$ \\
\hline Russia & $\pm 0,007 \mathrm{~m}$ & $\pm 0,028 \mathrm{~m}$ & $0,32 \mathrm{~m}$ & $\pm 1 \mathrm{~m}$ \\
\hline
\end{tabular}


As additional potential of quality problems, more than 10 years that have passed by after the demarcation of the boundary shall be considered. During this period the established network system was not maintained, and in both neighboring countries new and different geodetic reference systems were developed without performing their mutual synchronization - linkage. All pointed out to necessity to restore the established joint border geodetic reference network. In the same time, there are requirements and possibilities of contemporary geodetic measurement technologies. About such necessity specialists of both countries informed the joint border commission already before performance of control measurements. Commission looked through the results of measurements and gave the task for working group to plan project of restoration of border maintenance joint geodetic reference system in 2017 , in order to realize it in full extent in 2018.

Specialists, when they organized planning of restoration of joint geodetic network, took into account the conclusions made during the analysis of results of border demarcation works:

- If more attention is paid to creation of Geodetic Reference System of state border demarcation works and greater original investment is assigned to it, we can expect higher quality indicators at the completion of works (Ratkevics et al., 2016a);

- If investments in creation of geodetic reference system of state border demarcation works are reduced, even on the base of arguments, which encourages experts to such decision, reaching of quality indices required at the completion of works can be subjected to raised risks (Ratkevics et al., 2016b);

In the same time, conclusions defined in earlier researches were approved:

- Creation of joint geodetic base for processes of state border demarcation shall be regarded as mandatory consistent part of works of demarcation of any state border, regardless the degree of mutual integration of geodetic bases of specific neighbouring countries (Burban, 1999);

- Joint geodetic bases of good quality, networks of geodetic points created in the framework of them provide good base for unambiguous and highly accurate measurement of installed pillars of state border, for mutual control of measurements by experts of both countries (Ratkevics et al., 2016a).

Taking into account the obtained raised practical efficiency of the functioning of joint geodetic reference network, when base stations of global navigation satellite system (GNSS) of permanent activity were included - integrated on Latvian - Russian state border (Burban, 2012), experts of both countries agreed to use such possibility. In the vicinity of the border, from both sides of the border following functioning stations were available - two stations in the territory of Latvia and two stations in the territory of Belarus. Dagda and Daugavpils - in the territory of Latvia (in the system LatPos) (Sereda, 2018), Braslav and Verhnedvinsk -in the territory of Belarus. Network of these four stations after the exchange, alignment and comparison of accrued measurement data and comparison of results was decided to regard in future as base network of the maintenance of the border. In order to avoid complications in recalculation among different national geodetic coordinate systems of neighboring countries, commission made decision that experts of both parts use one unified coordinate system in border 
maintenance works in the future. As such system more exact model ETRS89 for European continent (Forsberg et al., 1997) of the internationally recognized geodetic reference system WGS84 and its expansion in the plane made in the zone 35 of UTM projection (Moritz, 1980). Usage of such system was well known in practice for experts of both countries.

It was decided to create the densifying part of the network from points of former joint geodetic network selecting points that are maximally near to the state border. Their functions were to provide accurate performance of geodetic measurements also in cases, if GNSS stations will not function or usage of them in individual places will encumbered in case of lack of open horizon (North Atlantic Treaty..., n.y.). In the territory of each country for this purpose 19 geodetic points were selected, controlled and prepared for measurement in Latvia and 18 geodetic points in Belarus until the beginning of 2018 (totally 39 points).

Points of earlier created network of GNSS stations - border maintenance base network were used as support points for measurement of points of densifying networks and calculations of coordinates. The solution allowed to carry out quality evaluation of base network points in the same time with creation and measurement of the densifying network. Quality evaluation was potential basic technology element for measurement of boundary problem places (Celms et al., 2018). In July 2018, experts of both countries performed joint measurement of densifying network points - carried out GPS data accumulation measurements for every point in two 2 hour sessions, changing the height of instrument between measurement sessions. Originally, it was offered to determine duration of sessions 4 hours (Zvirgzds, 2007). After evaluation of gained experience and results on other state borders it was agreed to reduce the duration of sessions. As a result, works of measurements of densifying points were carried out during one working week (see Fig 3).

The GPS (Turner, 2008) calculation in the receiver uses four equations in the four unknowns $x, y, z, t_{c}$, where $x, y, z$ are the receiver's coordinates, and $t_{c}$ is the time correction for the GPS receiver's clock. Example the four equations are:

$$
\begin{aligned}
& d_{1}=c\left(t_{t, 1}-t_{r, 1}+t_{c}\right)=\sqrt{\left(x_{1}-x\right)^{2}+\left(y_{1}-y\right)^{2}+{\sqrt{\left(z_{1}-z\right)}}^{2}} \\
& d_{2}=c\left(t_{t, 2}-t_{r, 2}+t_{c}\right)=\sqrt{\left(x_{2}-x\right)^{2}+\left(y_{2}-y\right)^{2}+{\sqrt{\left(z_{2}-z\right)}}^{2}} \\
& d_{3}=c\left(t_{t, 3}-t_{r, 3}+t_{c}\right)=\sqrt{\left(x_{3}-x\right)^{2}+\left(y_{3}-y\right)^{2}+{\sqrt{\left(z_{3}-z\right)}}^{2}} \\
& d_{4}=c\left(t_{t, 4}-t_{r, 4}+t_{c}\right)=\sqrt{\left(x_{4}-x\right)^{2}+\left(y_{4}-y\right)^{2}+{\sqrt{\left(z_{4}-z\right)}}^{2}}
\end{aligned}
$$

where

$$
c \text { - speed of light }\left(3^{\prime} 10^{8} \mathrm{~m} / \mathrm{s}\right)
$$

$t_{t, 1}, t_{t, 2}, t_{t, 3}, t_{t, 4}$ - times that GPS satellites $1,2,3$, and 4, respectively, transmitted their signals (these times are provided to the receiver as part of the information that is transmitted).

$t_{r, 1}, t_{r, 2}, t_{r, 3}, t_{r, 4}$ - times that the signals from GPS satellites 1, 2, 3, and 4, respectively, are received (according to the inaccurate GPS receiver's clock) 
$x_{1}, y_{1}, z_{1}$ - coordinates of GPS satellite 1 (these coordinates are provided to the receiver as part of the information that is transmitted); similar meaning for $x_{2}, y_{2}, z_{2}$, etc.

The receiver solves these equations simultaneously to determine $x, y, z$, and $t_{c}$ (Zagars, 2014).

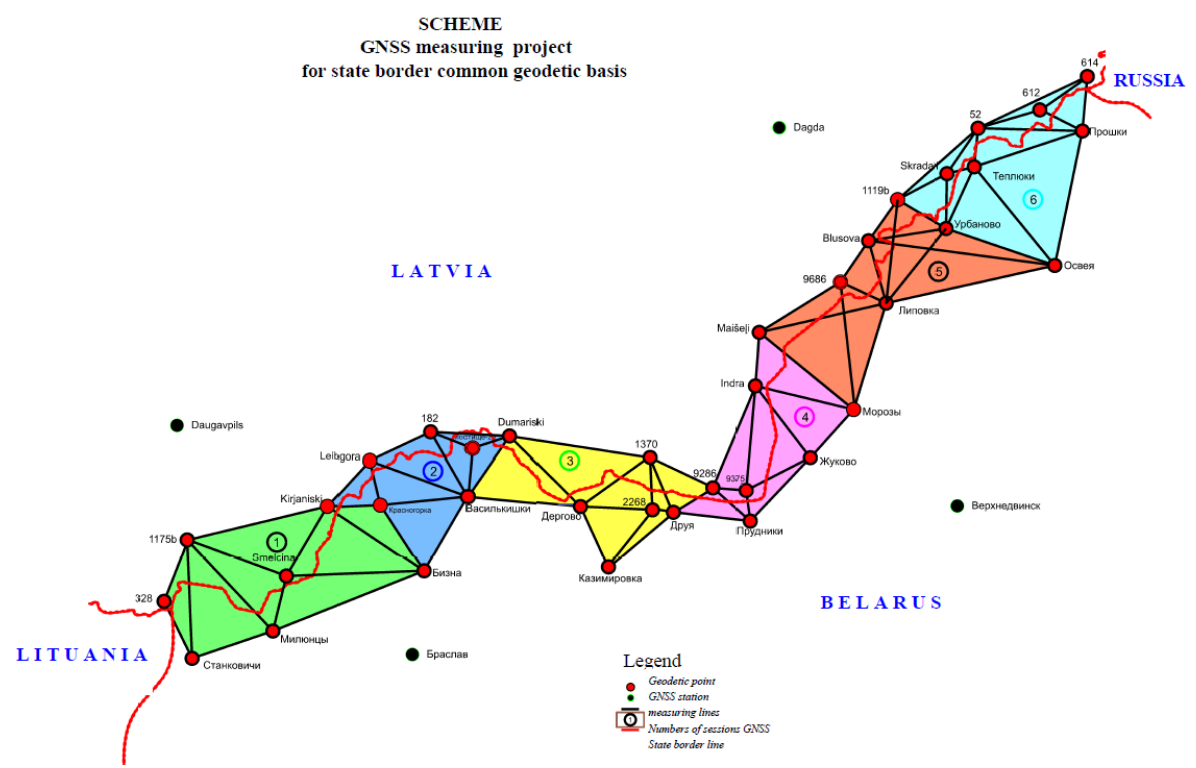

Figure 3. Scheme of Latvian - Belarussian State Border joint geodetic reference network and planning of measurement works (Document of joint border commission (Protocols..., n.y.))

\section{Results and discussion}

The selected procedure of creation of joint border maintenance geodetic reference network and technical solutions after the processing and alignment of measurement results demonstrated excellent results (see Table 2).

Table 2. Comparison of Latvian State Border geodetic reference base network point (GNSS) coordinates (document of joint border commission (Protocols..., n.y.))

\begin{tabular}{|c|l|c|c|c|}
\hline \multirow{2}{*}{ No } & \multirow{2}{*}{ Point name } & \multicolumn{3}{|c|}{ Belarus } \\
\cline { 3 - 5 } & & $\mathbf{X}(\mathbf{M})$ & $\mathbf{Y}(\mathbf{M})$ & $\mathbf{Z}(\mathbf{M})$ \\
\hline 1 & Браслав & 3214066.536 & 1640718.438 & 5241696.855 \\
\hline 2 & Верхнедвинск & 3175919.902 & 1684179.057 & 5251066.049 \\
\hline 3 & Dagda & 3162077.949 & 1648395.082 & 5270703.638 \\
\hline 4 & Daugavpils & 3209600.255 & 1601536.746 & 5256389.751 \\
\hline \multicolumn{2}{|c|}{ Latvia } \\
\cline { 3 - 5 } & $\mathbf{X}(\mathbf{M})$ & $\mathbf{Y}(\mathbf{M})$ & $\mathbf{Z}(\mathbf{M})$ \\
\hline 1 & Браслав & 3214066.537 & 1640718.446 & 5241696.865 \\
\hline 2 & Верхнедвинск & 3175919.903 & 1684179.065 & 5251066.060 \\
\hline 3 & Dagda & 3162077.952 & 1648395.089 & 5270703.649 \\
\hline 4 & Daugavpils & 3209600.258 & 1601536.752 & 5256389.762 \\
\hline
\end{tabular}


Maximal deviations for GNSS base stations of the network, if calculations carried out by experts of both countries self-dependently are compared, in coordinates $\mathrm{X}$ and $\mathrm{Y}$ did not exceed $8 \mathrm{~mm}$ limit. Slightly worse were results for $\mathrm{Z}$ component - maximal difference $11 \mathrm{~mm}$, but this deviation in all cases is almost equal with $1 \mathrm{~mm}$ difference in one direction, which allows systematic deviation in output height data (see Table 3 ).

Table 3. Deviations of Latvian State Border geodetic reference base network point (GNSS) coordinates (document of joint border commission (Protocols..., n.y.))

\begin{tabular}{|c|l|c|c|}
\hline No & Point name & \multicolumn{2}{|c|}{ Deviations } \\
\hline & & $\Delta \mathbf{Y}(\mathbf{M})$ & $\Delta \mathbf{Z}(\mathbf{M})$ \\
\hline 1 & Браслав & 0.008 & 0.011 \\
\hline 2 & Верхнедвинск & 0.008 & 0.010 \\
\hline 3 & Dagda & 0.007 & 0.011 \\
\hline 4 & Daugavpils & 0.006 & 0.011 \\
\hline
\end{tabular}

As works were continued, in relation to basic network points, experts of every country carried out calculations and alignment of points of densifying network selfdependently. Comparison of results demonstrated very good indicators. Maximal deviation in direction of coordinates did not exceed $\mathrm{X}-56 \mathrm{~mm}, \mathrm{Y}-29 \mathrm{~mm}$ and $\mathrm{Z}-$ $111 \mathrm{~mm}$ (Protocols..., n.y.).

\section{Conclusions}

1. Indicators of accuracy of the established network are considerably, ten times, better than criteria defined in the project initially;

2. The obtained accuracy of points of the network points to convincing possibility to reach in performance of further geodetic works, in processes of border maintenance the accuracies of instrumental measurements, maximal deviations of which will not exceed initially defined values - for border markers up to $30 \mathrm{~cm}$ and for obscure contours up to 1 meter;

3. Results of the measurements and alignment of the densifying network demonstrate that in cases, when accurate geodetic GNSS equipment will be used for measurement and direct linkage will be made to base stations of State Border Geodetic Reference Base network, the results of measurements will be within limits of $10 \mathrm{~cm}$;

4. The obtained accuracies point to warranted possibility to reach the best required accuracy indicators also in case, when RTC (real time correction) technologies will be used for surveying. Such possibilities exist at least for $60 \%$ cases of potential measurements, which will create considerable possibilities of economy of time and financial resources for organizers of measurements.

5. Obtaining of measurements of convincing accuracy by use of RTK technologies will reduce consumption of time necessary for the procedures of border maintenance. It will be possible to form and sign protocols of comparison results during the process of works - without postponing to next times of meetings or joint sittings.

6. Possibilities of contemporary GNSS technologies demonstrate convincing application of new, more efficient, more accurate and faster realizable possibilities for geodetic provision in the performance of state border maintenance works. 


\section{References}

Arhipov I. A., (2018) Теоретические и организационно - практические аспекты деятельности государства по организации международно-правового оформления государственной границы (Theoretical and organizational - practical aspects of the activities of the state on the organization of international legal registration of the state border). Веснік Гродзенскага дзярзжаунага універсітэта імя Янкі Купалы, Minck Серыя 1, Гісторыя і археалогія. Філасофія. Паліталогія; Том 10, № 3, 2018, ISSN 2076-4839 (In Russian).

Burban P. (1999) Опыт картографического обеспечения делимитации государственной границы между Российской Федерацией и Латвийской Республикой (Experience in cartographic support for the delimitation of the state border between the Russian Federation and the Republic of Latvia). Геодезия и картография. 1999. №3.C20-24. (In Russian).

Burban P. (2012) Опыт использования спутниковых технологий и данных дистанционного зондирования Земли при демаркации государственной границы. (Experience of using satellite technologies and remote sensing data in the demarcation of the state border). «Zemlja Belarusi». №3, Minsk 2012 g. pp. 6-8. (In Russian).

Celms A., Parsova V., Ratkevics A., Reke I. (2018) Development of implementation of geoinformation provision of state border demarcation works. Сучасні досягнення геодезичної науки та виробництва : Збірник наукових праць Західного геодезичного товариства УТГК. Львів, 2018. Вип. 1(35), pp. 50-55. ISSN 1819-1339.

Forsberg R., Kaminskis J., Solheim D. (1997): Geoid of the Nordic and Baltic Region from Gravimetry and Satellite Altimetry. In Gravity, Geoid and Marine geodesy. (Segawa, J., Fujimoto, H. and Okubo, S., eds.), IAG Symp. Series, 117, 540-547. Springer, Berlin Heidelberg.

Moritz, H. (1980) Geodetic Reference System 1980. Bulletin Geodesique, 1980. 54: 395-405.

North Atlantic Treaty Organization NATO Standartization Agency (NSA) STANAG 2215 IGEO (Edition 6) - Evaluation of Land Maps, Aeronautical Charts and Digital topographic Data; NSA(AIR)0935-IGEO/2215

Protocols of Latvia-Belarus State Border Commission 2015 - 2018, State Border Guard Archives.

Ratkevics A., Celms A., Baumane V., Reke I. (2016a) Decision of geodetic substantiation for border demarcation of Latvia. Universitatea Agrară de Stat din Moldova. Lucrări ştiinţifice. Chişinău, 2016. Vol.46 : Cadastru şi drept, p. 108-112

Ratkevics A., Celms A., Kukule I. (2016b) Geodetic base preparation for state border demarcation. Сучасні досягнення геодезичної науки та виробництва : Збірник наукових праць Західного геодезичного товариства УТГК. Львів, 2016. Вип. 2(32), pp. 70-78 ISSN 1819-1339

Sereda A. (2018) Latvijas - Baltkrievijas robežu karšu satura apjomu izmaiņu noteikšana laika periodā no 1994. gada līdz 2018. gadam (Determination of Changes in the Content of Latvian - Belarusian Border Maps in the Period 1994 - 2018). Students on their way to science, Latvia University of Life Sciences and Technologies, Jelgava, 2018. Volume 3, pp. 45-47. (In Latvian).

Turner D. A. (2008) U.S. Space-Based Positioning, Navigation, and Timing Policy, Programs, and International Activities. International Symposium on Global Navigation Satellite Systems, Space-based and Ground-based Augmentation Systems and Applications. Berlin, Germany, 11- 14 November 2008.

Zagars J., Zvirgzds J., Kaminskis J. (2014) Globālās navigācijas satelītu sitēmas (Global Navigate Satellite System), 2014.ISBN 978-9984-648-53-8 (In Latvian).

Zvirgzds J. (2007) Geodetic Measurements In GPS Base Station Network Latpos of Latvia. // RTU Zinātniskie raksti, sērija 11, sējums 2. Rīga, 2007. RTU izdevniecība. pp.81.-89. 